empirically to give the "best fit" when compared with subjective assessment of noise annoyance. ${ }^{8-10}$

SB and FM were supported by a grant from the Wellcome Trust.

\section{References}

${ }^{1}$ Falk, S A, and Woods, N F, New England fournal of Medicine, 1973, 289,

2 Woods, N F, and Falk, S A, Nursing Research, 1974, 23, 144

3 Ragan, C A, Medical Times, 1974, 102, 17.

${ }^{4}$ British Medical fournal, 1973, 4, 625.

5 Whitfield, S, Nursing Times, 1975, 71, 402.
${ }^{6}$ Murphy, F, Bentley, S, and Dudley, H A F. In preparation.

${ }^{7}$ Korsten, C W, and Vanos, G J, Proceedings of the Conference on Control of Noise. London, HMSO, 1962.

${ }^{8}$ Robinson, D W, The Concept of Noise Pollution Level, NPL Aero Report Ac 38. London, National Physical Laboratory, 1969.

${ }^{9}$ Robinson, D W, An Outline Guide to Criteria for the Limitations of Urban Noise. CP No 1112. London, HMSO, 1970.

10 Broch, J T, The Application of the Brüel and Kjaer Measuring Systems to Acoustic Noise Measurements, p 32. Naerum, Denmark, Brüel and Kjaer, 1971.

${ }^{11}$ Central Health Services Council. Standing Nursing Advisory Committee. The Control of Noise in Hospital. London, Ministry of Health, 1961.

${ }^{12}$ Ministry of Health, Hospital Design, note 4. London, HMSO, 1966.

(Accepted 3 October 1977)

\title{
Cimetidine for duodenal ulceration in patients undergoing haemodialysis
}

\author{
CIARAN C DOHERTY, F A O'CONNOR, K D BUCHANAN, MARY G MCGEOWN
}

British Medical fournal, 1977, 2, 1506-1508

\begin{abstract}
Summary
Peptic ulcer is a common problem in advanced renal failure, but most drugs for ulcers are hazardous in this condition. In a small open study cimetidine was given to nine patients with acid hypersecretion and endoscopically diagnosed duodenal ulceration who were undergoing haemodialysis. The patients obtained good pain relief and suffered no serious side effects. Both basal and stimulated acid output fell considerably and the plasma gastrin response to food increased during treatment. Two patients with recurrent vomiting during haemodialysis had a striking response to cimetidine, which suggested that such vomiting may be acid-mediated in some patients.

These preliminary results suggest that cimetidine may prove to be an advance in the management of peptic ulcer in uraemic patients.
\end{abstract}

\section{Introduction}

Peptic ulceration is unusually common in chronic renal failure, ${ }^{1}$ and this poses a difficult problem, since many drugs for ulcer may have undesirable side effects in the uraemic patient. The $\mathrm{H}_{2}$-receptor antagonist cimetidine is excreted mainly by the kidneys, but in patients on regular dialysis a reduced dose will produce adequate blood concentrations without the risk of accumulation. ${ }^{2}$ Furthermore, an acid-lowering drug is a logical approach in the uraemic patient, as pyloroduodenal ulcer pre-

Renal Unit, Belfast City Hospital, Belfast BT9 7AB

CIARAN C DOHERTY, MB, MRCP, senior registrar in nephrology MARY G MCGEOWN, MD, FRCP, consultant nephrologist

University Department of Medicine, Royal Victoria Hospital, Belfast BT12 6BA

F A O'CONNOR, MD, MRCP, senior medical registrar (now consultant physician, Altnagelvin Hospital, Londonderry)

$\mathrm{K}$ D BUCHANAN, MD, FRCP, professor of metabolic medicine dominates in this condition, and gastric hyperacidity is strongly implicated. ${ }^{3}$ We present here our preliminary findings in patients undergoing renal dialysis who suffered peptic ulceration and were treated with cimetidine.

\section{Patients and methods}

Nine patients were treated with cimetidine. All had end-stage chronic renal failure (creatinine clearances $<3 \mathrm{ml} / \mathrm{min}$ ) requiring support by regular haemodialysis, and all had endoscopically proved duodenal or pyloric ulceration with gastric acid hypersecretion (peak acid output $>45 \mathrm{mmol}(\mathrm{mEq}) / \mathrm{h}$ for $\mathrm{men},>30 \mathrm{mmol} / \mathrm{h}$ for women; or basal acid output $>5 \mathrm{mmol} / \mathrm{h}$ ).

Cimetidine was given for six weeks in a reduced dose of $400 \mathrm{mg} /$ day on non-dialysis days and $800 \mathrm{mg} /$ day on dialysis days, as a single haemodialysis is known completely to clear the drug from the blood. Maintenance treatment of $200 \mathrm{mg} /$ day was continued thereafter.

\section{ASSESSMENT}

The symptomatic response was recorded at the end of six weeks, and repeat endoscopy carried out in those who had an ulcer crater before treatment. (Repeat endoscopy was not carried out in those who initially showed chronic scarring and deformity). All patients had two pentagastrin tests and two standard meal tests to assess, respectively, the effect of treatment on gastric acidity and plasma gastrin response to food. The tests were performed before treatment and again at the mid-point of the initial six-week course. A $200 \mathrm{mg}$ dose of oral cimetidine was given one hour before the repeat test.

Gastric acidity was measured using the standard method of intramuscular pentagastrin stimulation $(6 \mu \mathrm{g} / \mathrm{kg}$ body weight), and plasma gastrin was measured by radioimmunoassay. ${ }^{4}$ (Normal values for plasma gastrin in this laboratory are $0-150 \mathrm{ng} / 1$.) The standard meal used consisted of $50 \mathrm{~g}$ carbohydrate, $18 \mathrm{~g}$ protein, and $20 \mathrm{~g}$ fat given as lean cooked ham, white crustless bread, butter, unsweetened orange juice, and a cup of tea with milk. The test was carried out after an overnight fast of 10 hours, and blood samples were withdrawn through an indwelling needle inserted into a forearm vein.

The following haematological and biochemical indices were measured on all patients before and after six weeks' treatment: total and differential white cell count, platelet count, and serum creatinine and transaminase concentrations.

The significances of differences were calculated using the paired $t$ test. 


\section{Results}

Clinical details before treatment are given in the table. All but one patient had dyspeptic symptoms of varying degree, and two also had persistent vomiting on days of dialysis. After six weeks' cimetidine treatment all but one patient, who had active ulcer craters, showed almost complete resolution of symptoms, and the two patients with

Clinical data before cimetidine treatment

\begin{tabular}{|c|c|c|c|c|c|c|}
\hline $\begin{array}{l}\text { Case } \\
\text { No }\end{array}$ & Sex & $\begin{array}{c}\text { Age } \\
\text { (years) }\end{array}$ & $\begin{array}{l}\text { Serum } \\
\text { gastrin } \\
(\mathrm{pg} / \mathrm{ml})\end{array}$ & $\begin{array}{c}\text { Basal acid } \\
\text { output } \\
(\mathrm{mmol} / \mathrm{h})\end{array}$ & $\begin{array}{l}\text { Peak acid } \\
\text { output } \\
(\mathrm{mmol} / \mathrm{h})\end{array}$ & Endoscopy \\
\hline $\begin{array}{l}1 \\
2 \\
3 \\
4 \\
5 \\
6 \\
7 \\
8 \\
9\end{array}$ & $\begin{array}{l}M \\
M \\
F \\
M \\
M \\
M \\
M \\
F \\
F\end{array}$ & $\begin{array}{l}33 \\
15 \\
40 \\
40 \\
48 \\
35 \\
48 \\
51 \\
20\end{array}$ & $\begin{array}{r}170 \\
120 \\
85 \\
120 \\
220 \\
235 \\
130 \\
205 \\
585\end{array}$ & $\begin{array}{l}2 \cdot 6 \\
9 \cdot 1 \\
6 \cdot 9 \\
3 \cdot 8 \\
7 \cdot 8 \\
8 \cdot 9 \\
3 \cdot 7 \\
3 \cdot 7 \\
9 \cdot 2\end{array}$ & $\begin{array}{l}47 \cdot 6 \\
31 \cdot 4 \\
23 \cdot 4 \\
78 \cdot 0 \\
41 \cdot 2 \\
61 \cdot 6 \\
67 \cdot 0 \\
52 \cdot 4 \\
38 \cdot 2\end{array}$ & $\begin{array}{l}\text { Chronic duodenal ulcer } \\
\text { Active duodenal ulcer } \\
\text { Active duodenal ulcer } \\
\text { Chronic duodenal ulcer } \\
\text { Chronicprepyloriculcer } \\
\text { Active duodenal ulce: } \\
\text { Active duodenal ulcer } \\
\text { Chronic duodenal ulcer } \\
\text { Chronic duodenal ulcer }\end{array}$ \\
\hline
\end{tabular}

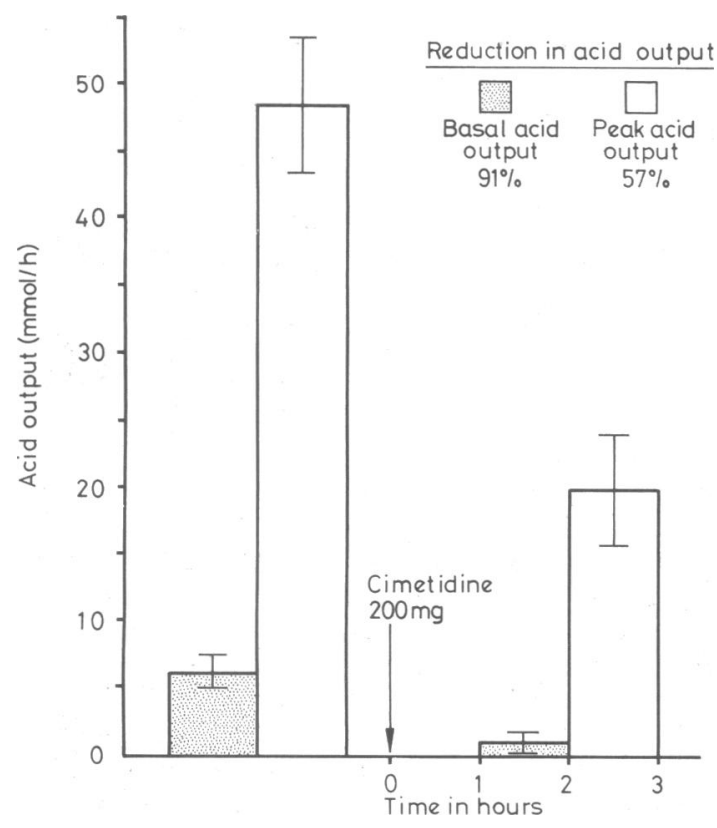

FIG 1-Effect of cimetidine on gastric acid secretion in eight uraemic patients with duodenal ulcer. Results are mean ( \pm SE of mean) basal and peak acid output before and after treatment.

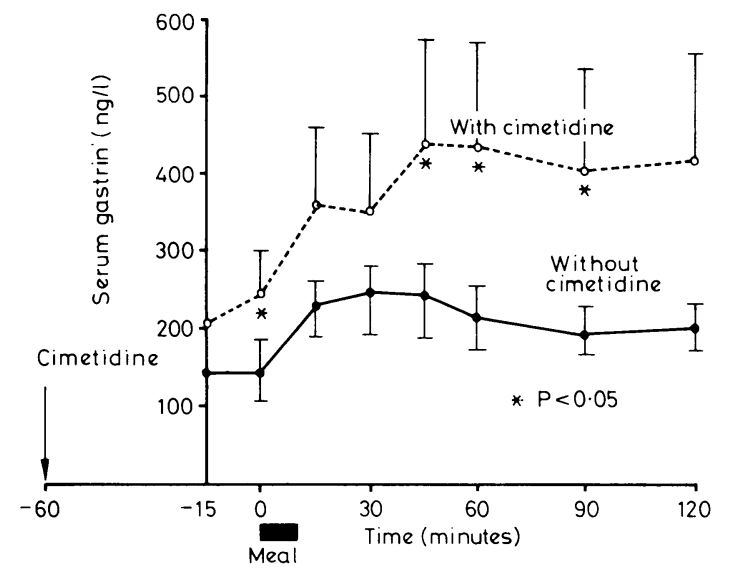

FIG 2-Effect of oral cimetidine on plasma gastrin response to food in eight uraemic patients with duodenal ulcer. Results are means ( \pm SE of mean).

Conversion: SI to traditional units-Acid output: $1 \mathrm{mmol} / 1$ $=1 \mathrm{mEq} / \mathrm{l}$. recurrent vomiting showed a quite dramatic response: their vomiting ceased immediately treatment began. The craters in the other three patients with active disease had healed by the end of six weeks. No serious side effects occurred.

When gastric acid was measured after three weeks' treatment both basal and stimulated acid output showed a considerable reduction (of $91^{\circ}{ }_{0}$ and $57^{\circ}$ o respectively; fig 1 ).

The repeat standard meal test showed that the serum gastrin response was increased significantly when the food stimulus was preceded by cimetidine (fig. 2).

No significant change was seen in the haematological or biochemical indices measured before and after treatment.

\section{Discussion}

Drugs for peptic ulcer may have serious side effects in the presence of impaired renal function, and most of the commonly used antacids fall into this category. Magnesium trisilicate mixture contains enough sodium to reverse the beneficial effects of the low sodium diets used in renal hypertension ${ }^{5}$; aluminiumcontaining antacids have recently been implicated in causing dialysis dementia ${ }^{6}$; calcium antacids have been shown actually to stimulate gastric acid secretion after the initial buffering action has occurred ${ }^{7}$; the liquorice derivatives affect sodium and potassium handling by the kidney; and bismuth toxicity may occur with preparations containing colloidal bismuth. Drugs that give symptomatic relief or heal ulcers are therefore potentially dangerous in patients with impaired renal function.

Our preliminary results show that cimetidine, in reduced doses, is well tolerated by patients with end-stage renal failure on maintenance haemodialysis. The acid suppression achieved is impressive in view of the fact that, under the conditions of this study, nasogastric aspiration may have removed some of the ingested dose. Cimetidine has been reported to increase plasma creatinine and serum transaminase concentrations, ${ }^{8}$ but we found no evidence of this among our patients.

The two patients with recurrent vomiting during haemodialysis showed a considerable improvement on cimetidine. Both showed abrupt cessation of vomiting followed by weight gain and improvement in general wellbeing. Both these patients had acid hypersecretion with pyloroduodenal scarring and deformity due to chronic ulceration. As basal gastric acidity is known to be increased by haemodialysis, ${ }^{9}$ this vomiting may have represented temporary pyloric obstruction due to acid-mediated mucosal oedema or spasm.

It may be suggested that the effect of cimetidine on gastrin release in response to food is undesirable when there is already a degree of gastrin overdrive on the parietal cell, as in the uraemic patient. Whether this will result in acid rebound on stopping treatment remains to be seen. Our overall impression from this preliminary study has, however, been favourable, and the results indicate that cimetidine should be further evaluated in this condition.

After kidney transplantation there is considerable mortality from upper gastrointestinal haemorrhage and perforation. ${ }^{10}$ There may therefore be a case for giving a prophylactic antisecretory drug to patients with duodenal ulcer and raised or normal gastric acidity during the high-risk period when corticosteroid dosage is necessarily high-that is, during the first six months after operation ${ }^{11}$ and later during rejection episodes. A significant proportion of uraemic patients are, however, hypochlorhydric or achlorhydric, ${ }^{12}$ and it is therefore irrational to advocate universal treatment with an acid-lowering drug. It is worth pointing out that ulcers should be sought by endoscopy. The barium meal examination in patients with chronic uraemia often shows a coarsening of mucosal folds, ${ }^{13}$ which makes interpretation of the radiological appearances difficult.

We must also emphasise that upper gastrointestinal tract complications after transplantation may be due to acute gastric erosions ${ }^{12}$ and the place of a prophylactic antisecretory agent in preventing these lesions is as yet undecided. Nevertheless, the 
incidence and severity of gastric erosions would clearly be minimised if drugs with an erosive influence (corticosteroids) were used sparingly and azathioprine and other cytotoxic drugs that may contribute a bleeding tendency (actinomycin C, cyclophosphamide, antilymphocyte globulin) given in as low a dosage as possible. Patients should also be warned of the danger of aspirin-containing preparations. ${ }^{14}$ Fibreoptic endoscopy and measurement of gastric acidity are therefore necessary to identify patients likely to benefit from prophylactic use of an antisecretory drug, and attention to immunosuppressive drug regimens is equally important. This seems preferable to prophylactic surgery, which is the policy in some dialysis centres. ${ }^{15} 16$

In conclusion, cimetidine may prove to be a considerable advance in the management of peptic ulcer in the uraemic patient and also in the prevention of upper gastrointestinal complications after transplantation.

We thank Sister Elizabeth Crawford and Sister Mabel Lindsay for carrying out the pentagastrin tests; the nursing, technical, and secretarial staff of the renal unit, Belfast City Hospital, and the technical staff of the department of medicine, Royal Victoria Hospital, for their co-operation in this study; and Miss Mary Martin for her secretarial help.

The work was supported by a grant from the Northern Ireland Kidney Research Fund.

\section{References}

${ }^{1}$ Langman, M J S, and Cooke, A R, Lancet, 1976, 1, 680.

2 Canavan, J S F, and Briggs, J D, in Proceedings of the Second International Symposium on Histamine $\mathrm{H}_{2}$-Receptor Antagonists. Amsterdam, Excerpta Medica, 1977.

${ }^{3}$ Doherty, C C, et al, Peptic Ulcer in Chronic Renal Failure. Submitted for publication.

${ }^{4}$ Ardhill, J E S, PhD Thesis, Queen's University of Belfast, 1973.

5 Beeley, L, Prescribers fournal, 1977, 17, 7.

6 Alfrey, A C, LeGendre, G R, and Kaehny, W D, New England fournal of Medicine, 1976, 294, 184.

${ }^{7}$ Barreras, R F, New England fournal of Medicine, 1970, 282, 1402.

8 Burland, W L, et al, Proceedings of the Second International Symposium on Histamine $\mathrm{H}_{2}$-Receptor Antagonists. Amsterdam, Excerpta Medica, 1977.

${ }^{9}$ Fung, W P, Lim, C H, and Tye, C Y, Annals of the Academy of Medicine of Singapore, 1974, 3, 379.

10 Ahonen, J, et al, Proceedings of the XIVth European Dialysis and Transplant Association. London, Pitman, 1977.

11 Starzl, T E, Experience in Renal Transplantation. Philadelphia, Saunders, 1964.

12 Doherty, C C, et al, Proceedings of the XIVth Congress of the European Dialysis and Transplant Association. London, Pitman, 1977.

13 Weiner, S N, Vertes, V, and Shapiro, H, Radiology, 1969, 92, 110.

${ }^{14}$ Doherty, C C, and Mary G McGeown, Lancet, 1977, 1, 1056.

${ }^{15}$ Hadjiyammakis, E J, et al, Lancet, 1971, 2, 781.

${ }^{16}$ Evans, D B, and Smellie, W A B, Clinical Organ Transplantation. Oxford, Blackwell, 1971.

(Accepted 30 September 1977)

\section{Glutamate dehydrogenase: a reliable marker of liver cell necrosis in the alcoholic}

LENA VAN WAES, CHARLES S LIEBER

British Medical fournal, 1977, 2, 1508-1510

\section{Summary}

The usefulness of blood enzyme determinations as markers of liver necrosis was tested in 100 alcoholics who underwent biopsy during clinical investigation. Mean values of glutamate dehydrogenase (GDH), serum aspartate and alanine transferase (SGOT and SGPT), ornithine carbamoyltransferase (OCT), and gammaglutamyltranspeptidase (gamma-GTP) tended to rise with increasing liver cell necrosis, though values of SGOT, SGPT, OCT, and gamma-GTP showed considerable overlap between the 32 patients with histologically proved hepatitis and the 68 without. By contrast, GDH values showed virtually no overlap between patients with and without hepatitis, and a value of two and a half times the normal value discriminated between the two groups.

Because of its easy determination and its reliable reflection of liver cell necrosis the GDH concentration should be estimated routinely in alcoholic patients.

\section{Introduction}

Liver cell necrosis is considered to represent an important factor

\footnotetext{
Alcohol Research Centre, Bronx Veterans Administration Hospital, and Mount Sinai School of Medicine, New York

LENA VAN WAES, MD, fellow

CHARLES S LIEBER, $M D$, director
}

in the progression of liver disease. Since repeat biopsies are impracticable for monitoring purposes, spill-over into the blood of the so-called liver enzymes, especially transaminases, is commonly used as a marker of liver cell necrosis. In the follow-up of patients with alcoholic liver disease, however, this approach has proved to be unsatisfactory. Blood transaminase concentrations are a poor reflection of liver cell necrosis. ${ }^{1}$ In alcoholic hepatitis, for example, concentrations of transaminases are only moderately raised and normal values are occasionally found. ${ }^{2}$ Moreover, transaminases are not liver-specific and raised concentrations may reflect, at least partly, damage to other organs. $\because$-Glutamyltranspeptidase $(\gamma-$ GTP) was recently suggested to be a useful marker of alcoholic liver disease. ${ }^{3}$ But although there is some correlation between raised $\gamma$-GTP concentrations and liver cell necrosis, ${ }^{4}$ raised concentrations may reflect only microsomal induction by alcohol in some cases, ${ }^{5-i}$ and increases produced by non-hepatic causes are common.

In an attempt to find a more suitable marker of liver necrosis in alcoholics, we focused on glutamate dehydrogenase (GDH) for various reasons. Firstly, it occurs predominantly in the liver, where its concentration ( $\mathrm{U} / \mathrm{g}$ protein) is 17 times that found in heart muscle, 80 times that found in skeletal muscle, and 28 times that found in pancreas. ${ }^{*}$ Secondly, its activity is $1 \cdot 7$ times greater in the centrolobular part of the liver, where alcoholic liver injury produces its major effects, ${ }^{9}$ than in the peripheral portion of the liver lobule. Thirdly, the enzyme is exclusively intramitochondrial, and mitochondrial damage due to alcohol has been documented. ${ }^{10}$

We tested the usefulness of $\mathrm{GDH}$ values in alcoholics by correlating the degree of liver cell necrosis with the blood enzyme value determined on the day of biopsy. Results were compared with those determined by estimating concentrations of conventional enzymes. 